\title{
The Family and National Development: How can the Family Forestall Future Insurgency Activities in the Nigerian Society?
}

DOI: http://doi.org/10.26758/8.1.23

Yinusa Mohammed (1), Oluyemi Joseph (1), Bashiru Salawu (1), Abdulateef Raji (1), Emmanuel Atolagbe (1), Adejoke Joseph (2)

(1) Department of Sociology, University of Ilorin, Ilorin, Nigeria

(2) Department of Medical Microbiology and Parasitology, Bowen University, Iwo, Nigeria.

Address correspondence to: Joseph Oluyemi, Department of Sociology, Faculty of Social Sciences, University of Ilorin, Kwara State Nigeria. Phone number: +234/018034205013. Email: josepholuyemi1@gmail.com

\begin{abstract}
Objectives. This study investigated the factors responsible for the Boko-Haram insurgency activities in North Central Nigeria, and how the family could help to forestall future occurrence of insurgent activities as an institution of change in the society.

Materials and Methodology. The study was conducted in Ilorin, headquarters of Kwara State North-Central region of Nigeria. 20 participants selected through purposive sampling method were included in the study. Information was retrieved through in-depth interviews with key informants while the study was explained by attachment and Social Control theories.

Findings. Results showed that poor parental training, poor parental values, poor parental care and poor parental monitoring and guidance are responsible for the involvement of children in insurgency activities in the region. However, child education, proper child upbringing, parent-child closeness, proper parental monitoring and parents being good examples to their children were suggested in the study as measures that could be put in place to forestall future occurrence of insurgency activities in Nigeria.

Conclusion and Recommendation. The study concluded that the role of the family in maintaining order in the society cannot be overemphasized and as such, parental attachment and control is imperative in the family. It, therefore, recommends that, in order to forestall future occurrence of insurgency activities in Nigeria, it is necessary for families to ensure that child-parent attachment and emotional support in the family is not lacking so that individuals do not become miscreants in the society and tools used by deviants to disrupt national development in the Nigerian society.
\end{abstract}

Keywords: parental closeness; parental monitoring; parental values; poor parental care; child education.

\section{Introduction}

National development, which is defined as the gradual manifestation of positive changes in the economic, industrial, political social, cultural and administrative life of a country (Ogai, 2007), is imperative to the continued existence of any society. However, the family, which is the cornerstone and the basic unit of social organization of the society, which carries out a vital task like socialization of the children, has a major role to play in ensuring that this role is played. Although 
no single definition of "the family" captures the many forms of family units around the world, The U.S. Census Bureau (2001) has defined the family as that which includes a householder and one or more people living in the same household who are related to the householder by birth, marriage, or adoption while the Population Reference Bureau (2000) described the family as a group of people held together by birth, marriage, or adoption or by common residence or close emotional attachment (Patterson, 2002).

However, in Africa, the family is seen in another dimension, more as an extended family comprising of a married couple, their offspring and immediate kith and kin-brothers and sisters of the bride, groom and the parents, relatives, in-laws and any other dependants (Nwobi, 1997). The family has been said to provide several important functions for society, some of which include: family formation, economic support, nurturance, and socialization, as well as protection of vulnerable members (Shaffer, 2000). Yet, despite this, it is sad to note that, many of the miscreants in the Nigerian society were born into one family or another. The Nigerian society recently is witnessing a high level of moral decay and there is an implosion in the number of youths and adolescents exhibiting anti-social and immoral behaviors (Nwosuji, 2008) causing a drastic change in the quality and quantity of relationships in the family (Ziehl, 2003).

Nigeria is faced with many inherent social problems, but in recent years the Boko Haram insurgency seems to be one of the most problematic issues that threaten the economic, political and social development of the country. The insurgent group whose official name is Jamā'atu Ahli'sSunna li'd-Da'wati wa'l-Jihād (an Arabic name that means Society of Adherents to the Prophet's Teachings Committed to the Propagation of the Faith and Jihad) was established in Maiduguri, the capital of Borno State Northeast Nigeria (Chothia, 2014) and has brought widespread insecurity to many parts of the region thereby threatening national development in the country. The lingering poverty in the country has caused many of Nigerian citizens to engage in social violence. Those Almajiri (child pupil) who are scattered all over the streets in northern Nigeria begging for alms (Shettima, 2009), are recruited to join Boko Haram and engage in violent aggression and other social and criminal activities of Boko Haram of suicide bombing. Many of these attacks have brought a serious paralysis to business activities in the region (Okereocha, 2012), leading to economic backwardness and consequently an increase of poverty, unemployment, insecurity, and failure of the sustainable human development (Shehu, 2015).

For almost a decade now, over 13,000 people have been killed while thousands of others have been displaced from their families especially in the northeastern region of the country the home of the sect (Shuaibu and Saleh, 2015), in a bid to flee for their dear lives. The question is, therefore: are not these individuals born into families with parents and significant others? The underlying assumption of the research is that a vacuum has been created by the family as a primary agent of socialization with the task of imbibing in children norms and values imperative to the development of their personality in order to help them contribute their quota to the peaceful coexistence of the society. It is against this backdrop that this study is been conducted.

\section{Theoretical Orientation}

\section{Attachment Theory}

Attachment theory was propounded by John Bowlby in 1969. The central focus of the theory is on the dynamics of long-term interpersonal relationship between people. According to Bowlby (1969), attachment begins in infancy and continues throughout the lifetime of a person. The theory proposed that an infant needs to develop a relationship with parents that will enhance the child's successful social and emotional development and in particular for learning how to effectively 
regulate their feelings. This attachment will create a bond between the child and parents, which will eventually pattern their relationship as the child grows in life.

Resting on the propositions of this theory, this study can be explained on the premise that, when a bond is formed between either the father or the mother and the child at infancy, such bond will develop into a form of intimacy, resulting into trust and cordial communication between parents and the child. This closeness is therefore expected to help children avert immoral behaviors and normlessness because parental closeness with the child may allow for proper socialization of the child by the parents in whom good moral values are inculcated into the children by the parents.

Attachment theory was however criticized for over blaming parents for what becomes of a child, bearing in mind that peer groups and environment have an equal influence on his evolution.

\section{Social Control Theory}

The social control theory of Iva Nye (1958) proposes that the process of socialization and social learning builds self-control and reduces the inclination to indulge in behavior recognized as antisocial. The theory postulates that-social control may come in the form of direct enforcement in which punishment is threatened or applied for wrongful behavior, while compliance to lay down rules is rewarded by parents, family and authority figures.

Building on this theory in explaining normlessness among children recruited into the Boko Haram insurgency group, it is assumed that if proper parental control is exerted on children, they would not be involved in such social vices, or this possibility would be considerably diminished.

Normlessness can be controlled directly by giving children standing rules, monitoring the kind of friends they associate with and staying out late or for a long time, and applying punishments when children deviate from them. This will serve as a deterrent to them and would avert future occurrence. It is also expected that if a child is aware that he/she will be punished for deviating from parental rules, there is an increased possibility that he/she would be willing to conform to such rules.

\section{Materials and Methodology}

This study was conducted in Irewolede area of Ilorin, headquarters of Kwara State, located in north-central Nigeria. The slogan for the State is "State of Harmony" because of the relative peace that is particular to the state and is being enjoyed by its inhabitants, thus serving as a refuge for many Nigerians seeking to reside in a peaceful environment. The city has was purposely selected for the study because of the relative peace that is being experienced in the State, which is the exact opposite of what entails in Maiduguri, the seat of the Boko Haram insurgence, so as to explore the factors responsible for the peace as it relates to the family when comparison is done and to determine how future insurgency activities in the region can be forestalled.

20 male family-heads, sixty years and above from diverse socio-economic backgrounds were purposively selected for the study. Although socialization of children in the family lies with both parents, male heads were selected for the study because, Nigeria is mainly a patriarchal society (Duze and Mohammed, 2006) in which family headship lies with the male. The families that were involved in the study have been able to raise their children successfully, reporting no cases of miscreants among them or anyone of the children as issues to the society. The qualitative method of inquiry that was used included an exploratory and explanatory case study approach to reveal the vacuum that has been created by the families in which members of the insurgent groups were born into. 
The particular choice of a qualitative approach was dictated by the intention to gain insight into how the family could help in curbing insurgency activities in Nigeria. Information was retrieved from participants through unstructured in-depth interviews. Informants' consent was sought before the interview was conducted and informants' identities were treated with anonymity to gain the informants' confidence. In order to protect the confidentiality of the informants, the identities of the informants were indicated solely by their age and occupation in the society.

\section{Results}

\section{How has the family been able to contribute to Boko Haram Insurgency in Nigeria?}

Participants in the study had varying views about how the family has contributed to the insurgency activities of the Boko Haram Sect in Nigeria. The following were some of the factors enumerated by the participants.

\subsection{Poor Home Training}

Many of the participants emphasized on lack of home training as a determining factor enhancing the participation of individuals from many families in the Boko Haram activities in the country. Some participants have this to say:

"As a Christian, the bible says we should train up a child in the way he should go and when he grows old he will not depart from it. When you don't train a child with the right morals, and instill the right values in him, especially at the formative stage, you can rest assured that the child will be a serious concern to the society. I believe children in the region where insurgency activities are happening are not adequately trained and as such it is easy for them to be recruited into insurgency groups" (medical doctor, 65 years).

Somebody else has something similar to say, listen to this:

"Normally, a child that is well trained from home and has the right value instilled into him/her will not likely be involved in unruly activities in the society. This entails the fear of God, the fear of elderly ones and the fear of the people around you. I believe whoever loves his fellow neighbor will not be involved in the killing of his neighbor" (petty trader, 62 years).

\subsection{Poor Parental Values}

Another issue mentioned by the participants in the study is that of the poor parental values among many parents in the families in the region where insurgency occurs. Some of the participants have this to say:

"I believe some parents themselves in this region where Boko Haram activities are predominant lack the right values and so they cannot pass the right values to their children. Many of them are not educated so do not know their right from their wrong. For example, many uneducated men in the region marry many wives and also give birth to so many children that they cannot fend for then what you expect from such a place" (retired civil servant, 66 years). 
In the same vein, another participant has this to say:

"Children who engage in insurgent activities don't know what they are doing, it is what they are asked to do that they do. The trouble starts with the parents; they are not performing their duties as parents. The question is that, do these parents know what is right from what is wrong? You can only give what you have; a parent that does not possess the right values cannot pass the right values to the child" (farmer, 62 years).

Another participant has something to say in line with this view, take a look at this:

"Of course.... It is mandatory that parents with wrong values will pass such values to their children. There is an adage that says, it is the thread that a mother pulls that the child will use. The bible also says that everything produces after itself. So if a father is a drunkard or promiscuous, there is every probability that children from such parent will produce such traits" (clergy, 68 years).

\subsection{Poor Parental Care}

Another family-related factor identified by the participants in the study as contributing to the insurgency activities in this region is poor parental care. The following are some of their submissions:

"Many of the parents from the families in which these children belong did not perform their duties as parents. I believe it is because parents from this region did not give their children adequate care, that is why these children give themselves up to Boko Haram" (artisan, 61 years).

Another participant has something similar to say, hear this:

"Well...it is because parents in this region do not cater for their children that is why many of them engage in unruly activities and join bad groups. There is an adage that says that to lose your child to death is better than the child being lost. In many families in this region, parents do not care about their children; whatever becomes of the child is the child's problem, and parents are not bothered about this. Early in the life of a child, he is given out by parents to their religious mallams who engage them in begging for alms and other derogatory activities which makes it easy for insurgent groups such as Boko Haram to recruit them" (businessman, 71 years).

\subsection{Poor Parental Monitoring and Guidance}

On parental monitoring, a participant has this to say:

"I believe the parents of these children have a fault in monitoring their children. The children are not adequately monitored by their parents, especially in the formative years of their lives. In a case where a man has many wives and many children whom they cannot cater for or even believe they are responsible for. Many of those children will lack parental guidance, and would not have someone they fear who can serve as a guide for them" (educationist, 69 years).

Similarly, another participant has this to say:

"Most of these children are not adequately guided especially in their childhood. I once lived among them and sometimes I ask myself, where are their parents. When they get to the age of 7 or 8 they 
are given out to the streets to go and beg for alms so as to sustain themselves. Many of these children do not have any form of address. In fact, whenever there is uproar anywhere they are the ones who are always used in such occasion. So they have no parental guidance a large number of them are people of no fixed address, so they don't really bother what is the consequences of their actions" (retired teacher, 64 years).

\section{How can the Family help to forestall future insurgency activities in Nigeria?}

Diverse opinions were given by the participants on what can be done by the family to forestall future occurrence of insurgency activities in Nigeria. These are some of their opinions.

\subsection{Child Education}

The need for proper and adequate education of the children was seriously emphasized as a measure to curbing the menace of insurgency activities in Nigeria and therefore ensuring national development in the country. For example, this participant has this to say:

"... Lack of education among the people in this region where insurgency activities occur is what causes this problem. It is therefore important that parents should give their children an adequate education. Once their parents give them the right education, the issue of insurgency will be a thing of the past" (lawyer, 66 years).

Similarly, another participant equally stressed the need for a proper and adequate education of children in the family as a way the family can help curb insurgency activities in the country. Listen to this:

"In order for Nigeria not to continue to witness insurgency activities in the country and to avoid trouble in the country every day, it is important for parents to take the issue of child education seriously. They should give their children a proper education. If this is done, the children will not grow up to become miscreants and menace to the society because they will be able to know what is good for them and how to plan their future" (lecturer, 64 years).

In the same vein, another participant has this view about education. Take a look at this:

"... Well, my advice to parents and families in this region is that they should allow these children to be sufficiently educated. Education is a liberator, if these children are given the needed amount of education, they would be able to see the weaknesses in their culture, the one they know would be too retrogressive for them to fulfill their destiny, and they will discard and encourage the one that will take them to where they desire to be in life. So education could be very costly, but the end result cannot be underestimated. If those children have decent and good education, there is every likelihood that their eyes will be open; nobody will just gather them in one corner and give them the wrong ideology that will be detrimental to their lives, destiny and the society at large. Therefore, no matter what the cost is, parents should invest in the education of their children" (retired teacher, 67 years) 


\subsection{Proper Child Upbringing}

Another way the family can help forestall future insurgency activities as enumerated by the participants in the study is to give children a proper upbringing as they grow up in life especially at the formative stage of their lives. Hear what this participant has to say:

"The role of the family in raising the child cannot be overemphasized. The family is a key to ensuring that children behave properly in the society by giving them the right orientation from childhood. I believe if children in the families in this region are given the right orientation especially during their formative years, they may not likely derail from them when they grow up in life" (businessman, 69 years).

Similarly, another participant has this to say:

"The way we behave in the society is a function of our upbringing in the family we are born into or raised. Even when the children come under peer pressure, and they have had a good upbringing in their formative stages in life, at that point that child will remember that, given whom I am, I cannot be involved in the wrong unruly behaviors. So if they have the right orientation from childhood, they are not likely to depart from it when they grow up" (trader, 66 years).

In the same vein, another participant has this to say:

"There is no doubt about it; many of the children who engage in insurgency activities in this region are not well brought up by their parents. I believe if the family over there can cooperate together and raise these children, they will be better children in society. Families should also give birth to children that they can afford to raise and bring up properly. The belief that God gives children and takes care of them should be seriously discouraged. People should only give birth to children that they can afford to raise rather than having children like chicken and leaving them for the society to cater for them and in the process exposing them to joining bad groups such as Boko Haram" (businessman, 71years).

\subsection{Parent-child Closeness}

Further findings from the study suggested that parental closeness with children could help forestall future insurgency activities in Nigeria. The following participants have these to say:

"From childhood, parents should create a bond with their children by ensuring that they are close to them. When parents are close to their children, children are likely not to be wayward. For instance, since my children were small, my wife and I were close to them, we read the Bible together, we prayed together and did many things together which they were able to pick from us and became part of them, which is instrumental to their success today. Children must be close to their parents; they must eat together, talk together, play together and laugh together. This will, therefore give them the opportunity to know the type of company they keep and once they want to start going wayward, it will be easy for their parents to detect and quickly address the situation. But when parents are not close to their children, they may be following the wrong company which the parents may not have the knowledge of" (retired civil servant, 66 years). 
Another participant has something similar to say, take a look at this:

"I will advise parents to be close to their children. Parental closeness to children will go a long way in curbing insurgency activities in Nigeria if this can be adopted by families in the country. For instance, I am very close to my children, I know all their friends and I scrutinize them even at their formative stages, this helped them as they grow up in life to become responsible children who are worthy of emulation" (businessman, 69 years).

\subsection{Proper Parental Monitoring}

A number of participants in the study stressed the need for parents to monitor their children as a measure that could be adopted in curbing insurgent activities in Nigeria. One of them has this to say:

"I believe when parents monitor their children properly, they will be able to check them early from unruly behaviors before it gets out of hand. My children, for instance, know I am a no-nonsense type, although I never beat anyone of them, but they distinguish what I want from what I don't want. I give them red lines that they must never cross, I don't joke with their academics, moral behaviors and their social behaviors and, of course, they know that they have to protect the name of the family by behaving well in the society. I am a close monitor father, when I see things with my children that are beyond what the family can afford, I query them so they know me from the world go that I will not take nonsense" (artisan, 61 years).

\subsection{Parents Being a Good Example to their Children}

Some of the participants emphasized the need for parents to lead by example. According to them, this would help the children to emulate the right values, which their parents try to imbibe on them. The following are some of the views of the participants as regards this:

"It is one thing to say a thing; it is another thing to do it. Many parents only tell their children what to do without them doing those things. The values most parents instill in their children are quite different from their own behavior. For instance, my wife and I are serious about our faith, we lived out our faith before our children and we taught them the Christian way and by the Grace of God, our children have tolled that path. So, whatever we do at home and in the larger society was geared towards our Christian faith and that was what our children also emulated, which by God's grace has helped them till today. So what parents do most times speak louder than what we say. By the Grace of God we didn't tell our children to do the right thing and then we do the wrong thing. Doing the right thing may be costly, but I think if parents learn to do what they preach to their children, our society will be a better place for us to live in" (medical doctor, 65 years).

This view is also in line with the view of this participant; hear what he has to say:

"I can say that, by the kind of life that I and my wife lived before our children, they have been able to emulate the right values from us, which has made them good children today. During their high school days, I specifically told them, never you ask for any help from anybody in any examination and never give such help because it will only help such people to deceive their world. And as a result of that, they never cheat on anyone or but only depend on what they could write in the examination hall and I, as their father, have never also had any reason to cheat in any examination from my elementary school to the time I graduated from the university. So it is not only enough for 
parents to instill the right values on their children but also to live by such examples" (retired teacher, 67 years).

\section{Discussions}

The study has been able to explore the contribution of the family to insurgency activities in Nigeria and how the family can help forestall future insurgency activities in Nigeria. One of the ways the family has contributed to these activities that were mentioned in the study is poor home training for the child. This result corroborates to the findings of Adnan, Arifin and Borhan (2014), in their research conducted on barriers to the moral development of children and parental responsibility. The finding also aligns with the view of Ismail (2014), who blames, for the insurgency activities, the prevailing almajiri system in the region and the inability of some parents to give their children adequate care and morals necessary to counter deviant behaviors.

Another way the family has been able to contribute to the insurgency activities in northeastern Nigeria is through poor parental values. This finding is in tandem with the research conducted by Jaccard et al. (1996) and Miller et al. (1999) on the significant effects of parental values on children behavior. Furthermore, insurgency activities in the region were also attributed to poor parental care prevalent in the region. This is also supported by the study carried out by Neema et al. (2006), which showed a relationship between children behavior and the emotional support provided by parents in the formative years of the child. This also validates the outcome of research conducted by Ngom, Magadi and Owuor (2003), which found that children living apart from parents and guardian represent a significant risk factor for the deviant behaviors.

At the same time, the problem of poor parental monitoring and guidance was also highlighted by the participants. This rests on similar result found in a cross-sectional and longitudinal study conducted by Romev et al. (1999), which found a significant relationship between parental monitoring and children negative behaviors. This also agrees with the study conducted by Diclemente, Crosby and Wingood (2002), which found a positive relationship between a lower level of perceived parental monitoring and several risky behaviors among children.

Nevertheless, one of the most important and efficient measures mentioned in the study on how the family can help forestall future insurgency in Nigeria is child education. This corroborates to the view of Rogers (2012), who opined that lack of adequate education is instrumental to the prevailing terrorism in the region. This finding is also in line with the view of Durotoye (2015) who asserted that lack of access to adequate education is one of the major causes of Boko Haram insurgency in the country. The focus of the participants on the role of proper upbringing in curbing the future occurrence of insurgency activity is similar to that of Hardon (1998) on the importance of family upbringing upon child development, resilience, and behaviors.

Furthermore, parental closeness was emphasized as imperative to curbing future insurgency in Nigeria. This confirms the conclusions of Neema et al. (2006), which showed a link between the emotional support that parents provide for children and delinquent behaviors. In addition, another measure that the family can put in place in curbing insurgency in Nigeria that was mentioned in the study by participants is proper monitoring and guidance by the parents. This rests on the views of Adewunmi, Olojo and Falemu (2012), who opined that the role of a parent to a child at any given time couldn't be overemphasized. This finding is also similar to the views of Wamoyi et al. (2011), on their study on parental control and monitoring of young people's behavior.

Finally, parents were advised to be good examples to their children, as this will go a long way in curbing insurgent activities in the country. This recommendation corresponds with the views 
of Geramian et al. (2012), who suggested that the influence of parental values on children behaviors couldn't be overemphasized.

\section{Conclusion}

This study investigated the family-related factors responsible for the Boko-Haram insurgency activities in the Nigerian society and how the family could help to forestall future occurrence of such activities as an institution of change in the society. The study was conducted in Ilorin, headquarters of Kwara State, North Central Nigeria. 20 participants that were selected through purposive sampling method were included in the study while information was retrieved through in-depth interviews with key informants.

Findings showed that poor parental training, poor parental values, poor parental care and poor parental monitoring and guidance are responsible for the involvement of children in insurgency activities in the region. However, child education, proper child upbringing, parent-child closeness, proper parental monitoring and parents being good examples to their children were suggested in the study as measures that could be put in place to forestall future occurrence of such activities.

The study concluded that insurgency activities of the Boko Haram sect in the country are also facilitated by the lack of parental attachment in the family and that children from such families are prone to become juvenile delinquents and deviants to the society. The study recommends improved child-parental attachment and emotional support for the child in the family to prevent them from becoming deviants in the society and being used as tools to disrupt National development.

\section{References}

1. Adewunmi, M.G., Olojo, O.J., and Falemu, F.A, 2012. Roles of parent on the academic performance of pupils in elementary schools. International Journal of Academic Research in Business and Social Sciences, 2(1). Available at: http://www.hrmars.com/admin/pics/487.pdf. [Accessed 31August 2017].

2. Adnan, A.R., Arifin, M., and Borhan, I., 2014. Barriers to Moral Development of Adolescents and Parental Responsibility: The Case of Malay Working Parents. International Journal of Humanities Social Sciences and Education, 1(6), pp.40-48. Available at: https://www.arcjournals.org/pdfs/ijhsse/v1-i6/6.pdf. [Accessed 30 August 2017].

3. Aguilar, T., 1999. Families of the New Millennium. Available at: http://www.prb.org/pdf/definingfamily.pdf. [Accessed 18 July 2017].

4. Aina, I.O., 1998. Women, culture and Society in A. Sesay and A.Odebiyi, eds. Nigerian Women in Society and Development. Ibadan: Dokun Publishing House/INTEC, pp.3-33

5. Anyadike, I. and Nkechi, O 2013. Boko Haram and National Security Challenges in Nigeria; Causes and Solutions. Journal of Economics and Sustainable Development, 4(5), pp 2222-2855.

6. Awogbenle, A.C. and Iwuamadi, K.C., 2010. Youth Unemployment: Entrepreneurship Development Programme as an Intervention Mechanism. African Journal of Business management, 4(6), pp.831-835.

7. Baumrind, D., 1991. The influence of parenting style on adolescent competence and substance use. Journal of Early Adolescence, 11(1), pp.56-95.

8. Bowlby, J., 1969. Attachment and Loss, Vol.1: Attachment. New York: Basic Books. 
9. Christian, L.G., 2006. Understanding families: Applying family systems theory to early childhood practice. Young Children, 61(1), pp.12-20.

10. Chothia, F., 2014. Who Are Nigeria's Boko Haram Islamists? BBC NEWS AFRICA, 20 May, Available at: http://www. bbc.com/news/world-africa-13809501.

11. Diclemente, R.J, Crosby, R.A, and Wingood, G.M., 2002. Enhancing STD/HIV prevention among adolescents: the importance of parental monitoring. Minerva pediatrica, 54(3), pp.171-7.

12. Durotoye, A., 2015. Economic consequences and management of Boko Haram insurgency in Nigeria, International Journal of Economics, Commerce and Management, 3(6). Available at: http://ijecm.co.uk/wp-content/uploads/2015/06/3675.pdf [Accessed 31 August 2017].

13. Duze, M.C. and Mohammed, I.Z., 2006. Male Knowledge, Attitude, and Family Planning Practices in Northern Nigeria. African Journal of Reproductive Health, 10(3) [online] Available at: https://www.ajol.info/index.php/ajrh/article/view/7899. [Accessed 30 August 2017].

14. Enrique, J., Howk, H., and Huitt, W., 2007. An overview of family development. Educational Psychology Interactive. Valdosta, GA: Valdosta State University. Available at: http://www.edpsycinteractive.org/papers/family.pdf. [Accessed 18 July 2017].

15. Geramian, N., Akhavan, S., Gharaat, L., Tehrani, A.M., Farajzadegan, Z., 2012. Determinants of drug abuse in high school students and their related knowledge and attitude. Journal of the Pakistan Medical Association, 62(3 Suppl 2), S.62-6. Available at: http://eprints.skums.ac.ir/id/eprint/5942 [Accessed 21 August 2017].

16. Hunter, J.E. and Schuman, N., 1980. Chronic reconstitution as a family style. Social Work, 25(6), pp.446-451.

17. Ismail, A., 2014. Panacea to Boko Haram Insurgency in Nigeria. The Nigerian Voice, 27 June, Available at: https://www.thenigerianvoice.com/news/150954/1/panacea-to-boko-haraminsurgency.html. [Accessed 30 August 2017].

18. Jaccard, J., Dihus D.J., \& Liturdo H.A, 1996. Parent adolescent communication about sex and birth control: Implication from parents based interventions to reduce unintended adolescent pregnancy. In: L.J Severy, W.B., Miller and L., Severy, eds. Advances in population. Psychological perspective, Vol. 3. London: Jessica Kingsley Publishers.

19. Kester, K.O., 2012. National Economic Transformation: Issues, Perspective and Challenges. A paper presented at the $10^{\text {th }}$ National Conference of the School of Arts and Social Sciences, Federal College of Education, Osiele, Abeokuta, Ogun State, Nigeria, $21^{\text {st }}-25^{\text {th }}$ May, 2012.

20. Miller, W.B., Pasta, D.J., Mac-Murry, J., Chiu, C., WU, H. and Coming, D.E, 1999. Dopamine receptor genes associated with age at first sexual intercourse. Journal of Biosocial Science, 31(1), pp.43-54.

21. Muhammad, A.P., and Joel, S 2012. Africa's Growing Giant - Population Dynamics in Nigeria. Population Dynamics in Muslim Countries pp 211-224. Available at: https://link.springer.com/chapter/10.1007/978-3-642-27881-5_13. [Accessed 30 August 2017].

22. Neema, S., Ahmed. F.H., Kibombo. R., Bankole, A., 2006. Adolescent sexual and reproductive health in Uganda: Results from the 2004 Uganda national survey of adolescents (Occasional Report No 26). New York: Guttmacher Institute.

23. Ngom, P., Magadi, M.A., Owuor, T., 2003. Parental presence and adolescent reproductive health among the Nairobi urban poor. Journal of Adolescent Health, 2003, 33(5), pp.369-377.

24. Nwobi,P.C., 1997. Marriage and Family Counselling. Enugu: Pan Africa Publishers.

25. Nwosuji, E., 2008. The role of husband \& wife in contemporary Nigeria society. Available at: http://nigsocioculture.blogspot.ro/2008/08/role-of-husband-wife-in-contemporary.html [Accessed 19 July 2017]. 
26. Nye, F.I., 1958. Family relationships and delinquent behavior. New York: Wiley; London: Chapman \& Hall.

27. Ogai, J.O., 2007. An Analysis of the concept of Development and Underdevelopment in Communication National Development. Available at: http://martinslibrary.blogspot.com/2014/05/the-meaning-and-concept-of-national.html. [Accessed 24 July 2017].

28. Ogunlesi, T., 2014. Nigeria overtakes South Africa to become Africa's largest economy. The Guardian, 7 April. Available at: https://www.theguardian.com/world/2014/apr/07/nigeria-southafrica-largest-economy [Accessed 30 August 2017].

29. Okereocha, C., 2012. Heartache for the Economy. TELL, May 14, pp. 46 -47.

30. Patterson, J.M., 2002. Understanding family resilience. Journal of clinical Psychology, 58(3), pp.233-246.

31. Rogers, P., April 3, 2012. Nigeria: the generic context of the Boko Haram Violence. Monthly Global Security Briefing, 30 April. Available at: http://www.oxfordresearchgroup.org.uk/sites/default/files/AprEn12.pdf. [Accessed 31 August 2017].

32. Romer, D., Stanton, B., Galbraith, J., Feigelman, S., Black, M.M., Li, X., 1999. Parental influence on adolescent sexual behavior in high poverty setting. Archives of pediatrics \& adolescent medicine, 153(10), pp.1055-62.

33. Shaffer, D.R., 2000. Social and personality development (4th ed.). Belmont, CA: Wadsworth.

34. Shehu, S. 2015. The impact of Boko Haram on Nigerian national development. In: Universiti Sultan Zainal Abidin, Malaysia, International Conference on Empowering Islamic Civilization in the $21^{\text {st }}$ Century. Kuala Lumpur, Malaysia, 6-7 September 2015. Available at: https://www.unisza.edu.my/icic/images/Fullpaper/06___Sani_Shehu.pdf. [Accessed 24 July 2017].

35. Shettima, A.G., 2009. The Almajiri syndrome: A response to General Babangida. Available at: http://www.amanaonline.com/Arti cles/Shettima/Shettima_30.htm [Accessed 24 July 2017].

36. Shuaibu, S.S. and Saleh, M.A., 2015. Historical evolution of Boko Haram in Nigeria: causes and solutions. In: Universiti Sultan Zainal Abidin, Malaysia, International Conference on Empowering Islamic Civilization in the $21^{\text {st }}$ Century. Kuala Lumpur, Malaysia, 6-7 September 2015. Available at: https://www.unisza.edu.my/.../Fullpaper/20_-_Salisu_Salisu_Shuaibu.pdf [Accessed 30 August 2017].

37. von Bertalanffy, L., 1968. General System Theory: Foundations, Development, Applications. New York: George Braziller.

38. Wamoyi, J., Fenwick, A., Urassa, M., Zaba, B. and Stones, W., 2011. Parental control and monitoring of young people's sexual behavior in rural North-Western Tanzania: Implications for sexual and reproductive health interventions. BMC Public Health (online), 11:106. Available at: https://bmcpublichealth.biomedcentral.com/articles/10.1186/1471-2458-11-106 [Accessed 31 August 2017].

39. Ziehl, S.C., 2003. Forging the links: Globalization and family patterns. Society in Transition, 34(2), pp.320-337.

40. ***International Crisis Group. Curbing Violence in Nigeria (II): The Boko Haram Insurgency. Report No.216 / AFRICA. Available at: https://www.crisisgroup.org/file/1094/download?token=Ybn0wuzJ [Accessed 30 August 2017].

41. ***IRIN (Integrated Regional Information Networks), 2013. Updated timeline of Boko Haram attacks and related violence, 12 Dec. Available at: 
http://www.irinnews.org/report/99319/updated-timeline-of-boko-haram-attacks-and-relatedviolence [Accessed 23 July 2017].

42. ***National Consortium for the Study of Terrorism and Responses to Terrorism, a Department of Homeland Security Center of Excellence led by the University of Maryland, 2014. Boko Haram recent attacks (START Background report). Available at: http://www.start.umd.edu/sites/default/files/files/STARTBackgroundReport_BokoHaramRecent Attacks_May2014_0.pdf [Accessed 29 August 2017].

43. *** Population Reference Bureau, 2000. Conveying concerns: Women report on families in transition. Available at: https://www.popline.org/node/242558 [Accessed 31 August 2017].

44. ***U.S. Department of State, 2014. Country reports on terrorism 2013. Available at: https://www.state.gov/documents/organization/225886.pdf [Accessed 30 August 2017].

45. ***U.S. Census Bureau, 2001. Census 2000 Profiles of General Demographic Characteristics. Available at: http://www.census.gov/prod/cen2000/doc/ProfilesTD.pdf. [Accessed 18 July 2017].

46. ***Voice of America, 2014, Boko Haram Claims Lagos, Abuja Attacks. VOA News, 14 July. Available at: http://www.voanews.com/content/boko-haram-claims-lagos-abujaattacks/1956928.html. [Accessed 23 July 2017]. 